\title{
Accountability in Government Contracts: A Measure of Performance from the Commitment-Making Officials?
}

\author{
Mohammad Zamroni \\ Faculty of Law, Universitas Hang Tuah, Indonesia. \\ E-mail: zamroni@hangtuah.ac.id
}

\begin{tabular}{l} 
ARTICLE INFO \\
\hline Keywords: \\
Accountability; Contract: \\
Government Contracts; \\
Commitment-Making \\
Officials \\
How to cite: \\
Zamroni, Mohammad \\
(2019). "Accountability in \\
Government Contracts: A \\
Measure of Performance \\
from the Commitment- \\
Making Officials?" \\
Hasanuddin Law Review, \\
5(2): 199-208 \\
DOI: \\
10.20956/halrev.v5i2.1074 \\
\hline
\end{tabular}

\begin{abstract}
Public-private partnership is an alternative defrayal which gives chances for private sectors to get engaged in financing the government's good and service suppliers through business contract. As contracts commonly made, failure may happen while implementing the contract, known as a tort. Therefore, government contracts are conducted by Commitment-Making Officials (hereinafter, PPK), authorized to make and implement it. Thus, the accountability over the contract failure is inseparable with the authorized PPK. This study aimed to examine the accountability of PPK when failures happen in the implementation of government contract. This paper using legal research method along with statute and conceptual approaches, the finding showed that PPK were accountable both as officials and individual. As officials, their accountability is apparent when they did tort on the provision mentioned in a government contract they had signed and established. As individuals, their accountability is apparent on which they did maladministration.
\end{abstract}

\section{Introduction}

Government, in performing its function, always seeks to provide goods and service for the people. it may be in the form of both infrastructural development and public service. However, the limitation of national budget often reveals as hindrance. Therefore, the utilization of public-private partnership is considered as an alternative financial mechanism the government establishes to provide public service by utilizing the private capital in the form of partnership.

A concept of utilizing private capital to provide public facilities is actually not new. In $18^{\text {th }}$ century and early $19^{\text {th }}$ century, Britain groups of local magnates established turnpike trust, taking loans from private investors for road repairing and paid it back from charging tolls. All Britain bridges were charged with a kind of bridge trusts until the mid$19^{\text {th }}$ century as well as the Brooklyn Bridge built by private capital in New York until the 
end 19th century. In France, the construction of canal using private capital had been conducted since $17^{\text {th }}$ century. ${ }^{1}$

Public-private partnership is often seen as an alternative defrayal by the government by giving chances for private sectors to participate in financing goods and public service procurement through partnership contract. ${ }^{2}$ Utilizing the contract as an instrument to maintain these governmental matters is known as contractualization. ${ }^{3}$

The government may use contractualization to create contractual partnership whether aiming to spend the national budget or to create relationships for gaining national income. Kinds of contracts the government acts as the contracting party is known as government contracts. Commonly, government contract is made and implemented by the Commitment-Making Officials (Pejabat Pembuat Komitmen or commonly known as 'PPK' in Indonesian). In article 1 section (7) Presidential decree No. 54, 2010, lastly amended by Presidential decree No. 70/2012 on government goods/service procurement, mentioned that PPK as officials were responsible to the operationalization of good/service procurement. PPK' functions include establishing contractual drafts, signing contracts/agreements, implementing the signed contracts, and controlling the implementation of the contracts.

Similar to private contracts, government contracts have some principles and legal norms commonly applied in contract law, such as consensualism and good faith. However, since government contracts relate to national finance, the responsibility of the contract must rely on the principles of transparency and accountability.

The emerging mark-up practices in contracts of goods and service procurement, and mark-down practices in non-procurement such as swapping (ruislag) inevitably often put the country into disadvantageous position, both in budget income and expense. Such deceitful practices may have even led the officials of former officials to jail. In many criminal cases committed by public officials, Dennis F. Thompson ${ }^{4}$ argued that many public officials from different instances, through various ways, had contributed to government decisions and policies, thus, it seemed difficult to search for principles to identify whoever morally responsible to political products.

As there are many hands from public officials may get engaged in a crime, three types of moral responsibility for stakeholders are then identified as follows: First, hierarchical responsibility. It is a type of responsibility for a political product assigned to number one top stakeholder in a chain of formal and informal authorities; Second, collective responsibility. It is based on an idea that many political products derive from various actions of different people, thereby, individual's contribution may not be identified at all and, indeed, it cannot be really distinguished from other's contributions; Third, personal responsibility. It relates responsibility with officials as personal, and not only as given stakeholders or as members of collectives.

For this reason, the officials' accountability in making and implementing government contracts needs to be investigated. As the scope of this study, the discussion might focus

\footnotetext{
1 E.R. Yescombe and Edward Farquharson. (2018). Public Private Partnerships for Infrastructure: Principles of Policy and Finance. 2nd Edition. Oxford: Elsevier Ltd. p. 5.

2 Tim AFDES. (2013). Kerjasama Pemerintah Swasta. Jakarta: Aid for Development Effectiveness Secretariat. p. 1.

3 Peter Vincent-Jones in Pekka Valkama, Stephen J. Bailey and Ari-Veikko Anttiroiko (ed). (2013). Organizational Innovation in Public Services, Forms and Governance. London: Palgrave Macmillan. p. 238.

4 Dennis F. Thompson. (2000). Political Ethics and Public Office. Translated by Benyamin Molan-Ed. Jakarta: Yayasan Obor Indonesia. pp. 48-59.
} 
on government contracts made and implemented by PPK; officials responsible to the implementation of goods and service procurement.

\section{Method}

Given that legal studies are sui generis, this study applies legal research method, and the approaches used here are statute approach and conceptual approach. It moves to civil law system in which the primary law is legislation (reasoning based on rules). Investigation on regulation particularly focuses on finding out the basic authority of PPK. Legal data of this study consist of primary law and secondary law. Primary law is in the form of regulations, including Burgerlijk Wetboek Stb. 1847-23; the Law No. 37/ 2008 on Ombudsman of the Republic of Indonesia; and Presidential decree No. 54/ 2010, as lastly amended by Presidential decree No. 70/2012, on government goods/service procurement. Secondary law, on the other hand, includes legal writings in textbooks, journals, academic texts, paper, and other related documents.

This study is library-based, including digital-library-based. Data collection begins with inventorying laws which are then identified using research approaches. The gathered legal data are then critically and systematically analyzed. It begins with examining the construct of accountability in government contracts. Then, it moves to analyze some regulations related to the research issue. The analysis focuses on finding the accountability of the PPK in the implementation of government contract.

\section{Accountability in Civil Law and Public Law}

Accountability is quintessence of any corporate governance debate despite that there is no unified doctrine what accountability consists of. ${ }^{5}$ The term accountability is defined as a state of being responsible to things (can be blamed and charged when things go wrong). Peter Mahmud Marzuki ${ }^{6}$ referred the concept of accountability to the term liability/aansprakelijkheid identified as a specific form of responsibility. Thus, the definition of accountability points to individual or corporation considered liable to pay a kind of compensation or amends due to legal action. The concept of accountability is within the scope of private law.

A construction of legal relationship which reveals accountability (aansprakelijkheid) my happen due to tort and legal violation (onrechtmatige daad). ${ }^{7}$ Similarly, Jacob Hans Niewenhuis argued that accountability referred an obligation to bear amends due to tort or any actions against the law. 8 Kinds of accountability include fault-based accountability, risk-based accountability, sharpened accountability (shifting burden of proof), absolute accountability, limited accountability, etc.

Dealing with risk-based accountability, Niewenhuis cited the provision of article 1367 section (3) Burgerlijk Wetboek as an example, an employer was accountable for amends due to his employees' lawlessness within the scope of his order. Nieuwenhuis 9

5 Natalya Mosunova. (2014). “The Content of Accountability in Corporate Governance”. Russian Law Journal, Volume II, Issue 3: 116-129.

6 Peter Mahmud Marzuki. (2013). Pengantar Ilmu Hukum. Jakarta: Kencana Prenada Media. p. 220.

7 Agus Yudha Hernoko. (2016). "Prinsip-prinsip Tanggung Gugat Keperdataan". Paper. Surabaya: Fakultas Hukum Universitas Airlangga. p. 35.

8 Jacob Hans Nieuwenhuis. (1985). Hoofdstukken Verbintenissenrecht. translated by Djasadin Saragih. Surabaya: Universitas Airlangga. pp. 116-117.

${ }^{9}$ Ibid. p. 138. 
elaborated Risk-based accountability in article 1367 section (3) Burgerlijk Wetboek as follows.

a. Accountability in article 1367 section (3) Burgerlijk Wetboek relies on the relationship between superiors and subordinates. What decisive here is an authority to give instruction to others. This authority may reveal from employment contracts, or, it may also derive from public law such as the relationship between ruler and the officials.

b. Toward accountability in article 1367 section (3) Burgerlijk Wetboek indicates the presence of lawlessness and subordinates' fault

c. Accountability does not depend on lawlessness or fault by superiors. The injured parties need to hold onto evidence of the lawlessness by subordinates, superiorsubordinate relationship, and a fact that subordinates' tasks may open opportunities to act against the law. Any personal defense that it is not regretted may not be able to help the employer at all (risk-based accountability)

Initially, one's accountability is identified solely based on civil law. Along with its development, however, accountability is also based on public law. Dealing with this, Tatiek Sri Djatmiati10 identified such accountability as both personal responsibility and job responsibility. Personal responsibility is related to functionary approach of behavioral approach. In the context of administrative law, personal responsibility refers to maladministration issue on authority toward public service. The use of authority intended here involves governmental measure based on regulations and establishing a particular policy or discretion. Personal responsibility does not recognize the principle of "Respondeat Superior" (the superior is responsible for his subordinates' behavior). ${ }^{11} \mathrm{Job}$ responsibility, on the other hand, is related to legality of government measure in administrative law. The legality is associated with approaches toward the government power. Approaching such power has relation with authorized incumbency following regulation based on the principle of legality or rechtmatigheid principle. Any differences between personal responsibility and job responsibility over the government measure bring several consequences related to criminal responsibility, civil/private responsibility, and administrative responsibility.

\section{The Authority of Commitment-Making Officials in Government Contract}

The term 'authority' and 'the authority' often stand in line with a Dutch legal term "bevoegdheid". Carefully investigated, however, little bit difference is found between the term 'authority $\mathcal{E}$ the authority' and the term bevoegdheid. The difference is on their legal features. The Dutch's term bevoegdheid is used in both public and private laws. In Indonesia, however, the term 'authority' and 'the authority' are always used in public law. In the context of constitutional law, the term authority (bevoegdheid) is described as legal power (rechtsmacht). That is, in public law, authority relates to power. Thus, the concept of authority refers to the concept of public law. ${ }^{12}$

10 Tatiek Sri Djatmiati in Philipus M. Hadjon, et.al. (2010). Hukum Administrasi dan Good Governance. Jakarta: Universitas Trisakti. pp. 94-96.

11 See Michael Harper. (2017). “Using the Anglo-American Respondeat Superior Principle to Assign Responsibility for Worker Statutory Benefits and Protections". Public Law Research Paper. Boston University. School of Law. pp. 85.

12 Nicken Sarwo Rini. (2018). “Penyalahgunaan Kewenangan Administrasi dalam Undang-Undang Tindak Pidana Korupsi". Jurnal Penelitian Hukum De Jure. Vol.18 No.2. Juni: 257-274. 
Government contract is a contract in which government gets engaged as contracting party. Government contract can be in the form of either procurement or nonprocurement contract. The difference between them is on their contractual purposes. Procurement contract is not solely in the frame of procurement. Rather, it included many facets for public service purposes. In the perspective of Indonesia, such difference may be found in budget as well. Referring to this aspect, procurement contract raises expense, while non-procurement contract raises income. ${ }^{13}$ Dealing with government contract commonly held, it is found that this kind of contract is considered categorized into private law. Thus, the legal principles contained in contract law are basically applied in government contract. ${ }^{14}$

Government contract is one government measure. Following Van Vollenhoven, what is meant by government contract (bestuurshandeling) is spontaneous and distinctive maintenance of national interests by higher and lower authorities. ${ }^{15}$ The government measure can be conducted by various bodies, including:

a. Conducted by the state administrative agency itself

b. Conducted by another legal subject outside the state administrative agency, conducted based on idiosyncratic relationship.

c. Conducted by another legal subject working based on a particular concession/under government's authority, and outside the state administrative agency.

d. Conducted by another legal subject having subsidy from government and outside the state administrative agency.

e. Conducted by government along with another legal subject outside the state administrative agency, and both them are unified through partnership.

f. Conducted by institutes the government builds/supervises.

g. Conducted by cooperative the government builds/supervises.

h. Conducted by state-owned companies.

According to Sukardja, 16 government administration's measure conducted by government officials can be classified into two categories, including legal action and common action. Legal action involves both public and private laws. These actions is conducted by legal bodies or state administrative officials always based on regulation, unless they need to do quick-action which legal provision is not yet established.

The discussion of the government's measure itself is inseparable with government's authority to act. The uthority was a key concept of both administrative and constitutional laws. However, F.P.C.L. Tonner argued, "Overheidsbevoegdheid wordt in dit verband opgevad als het vermogen om positief recht vast te srellen en Aldus rechtsbetrekkingen tussen burgers onderling en tussen overhead en te scheppen," that is, government authority is considered as a capacity to implement positive law, and thus, it may reveal from legal relationship between government and the people. ${ }^{17}$

13 Yohanes Sogar Simamora. (2013). Hukum Kontrak, Kontrak Pengadaan Barang dan Jasa Pemerintah di Indonesia. Surabaya: Laksbang Justitia. p. 47.

14 Ibid., p. 14.

15 I Dewa Gede Atmadja and I Nyoman Putu Budiartha. (2018). Teori-Teori Hukum. Malang: Setara Press. p. 160.

16 Ahmad Sukardja. (2012). Hukum Tata Negara \& Hukum Administrasi Negara Dalam Perspektif Fikih Siyasah. Jakarta: Sinar Grafika. p. 243.

17 HR. Ridwan. (2006). Hukum Administrasi Negara. Jakarta: Rajawali Pers. p. 100. 
Prajudi Atmosudirdjo argued that authority was what known as formal power; a power derived from legislative rules (provided by regulations) or from administrative rules. The authority is dominance toward a particular group of people or toward a whole government body, while authority merely refers to particular spare parts of a body. The authority includes various authorities. Authority is a competence to do public legal actions. ${ }^{18}$

In administrative law, there were two primary ways to get government authority; attribution and delegation. Mandate, sometimes, is also considered as an exclusive way to get the authority when it is associated with administrative lawsuit. Mandates may not be exclusive since the mandated cannot be imposed as defendant in an administrative court. 19

Authority through attribution is a new government authorization based on a particular provision in legislation. Thus, a new government authority reveals. Authority through delegation is devolution of existing authority by the official of the state administrative body having attributive government authority to another official of the state administrative body. Therefore, a delegation is always preceded by an authority attribution.

In mandate, however, neither new authority attribution nor delegation may happen from one official to another official of the state administrative body. ${ }^{20}$ In addition, H.D. van Wijk/Willem Konijnenbelt identified attribution (attributie), delegation (delegatie), and mandate (mandaat) as follows:

a. Attributie: toekenning van een bestuursbevoegdheid door een weigever aan een bestuursorgaan;

b. Delegatie: overdracht van een bevoegheid van het ene bestuursorgaan aan een ander;

c. Mandaat: een bestuursorgaan laat zijn bevoegheid namens hem uitoefenen door een ander. ${ }^{21}$

The government measure did not always have to rely on a legitimate authority. The authority may derive from attribution, delegation, and mandate. The authority through attribution is commonly outlined by the division of the state power under the constitution, while the authority through delegation and mandate comes from devolution. 22

In government contract setting, the authority of PPK is described in Presidential decree No. 54/2010, as lastly amended by Presidential decree No. 70/2012, on government goods/service procurement. PPK are the officials assigned by Budget User or Proxy of Budget User to do goods/service procurement. The authority of PPK, as mentioned in article 11, involves:

a. Establishing goods/service procurement planning which consists of:

1) Technical specification of goods/service;

2) Owner estimate; and

18 Prajudi Atmosudirdjo. (1981). Hukum Administrasi Negara. Jakarta: Ghalia Indonesia. p. 29.

19 Ibid., p. 2.

${ }^{20}$ Ekaterina Kolpinskaya, et.al. (2019). “Mandates Matter: How Decisive Victories Enhance Expectations About Government Performance". Journal Election, Public Opinion and Parties. April 2019: 1-20. DOI: 10.1080/17457289.2019.1599004.

21 H.D. van Wijk/Willem Konijnenbelt. (1988). Hoofdstukken van Administratief Recht. Culemborg: Uitgeverij LEMMA BV. p. 56.

22 Neculai Lungeanu. (2017). "Conceptual Aspects of the Legislative Delegation within the Romanian Law and the Law of other States". Acta Universitatis Danubius. Vol.9, No. 2. pp. 60-72. 
3) Draft of contract

b. Establishing SPPBJ (letter of intent for goods/service procurement)

c. Signing the contract

d. Implementing the contract with goods/service provider

e. Controlling the implementation of the contract

f. Reporting the implementation/completion of goods/service procurement to the Budget User/Proxy of Budget User

g. Submitting the result of goods/service procurement to the Budget User/Proxy of Budget user by record of transfer

h. Quarterly reporting the progress of performance including budget absorption and limitation of performance to the Budget User/Proxy of Budget User

i. Keeping and maintaining the totality of documents on the implementation of goods/service procurement.

\section{Maladministration on Implementing Government Contract}

There are two kinds of government contract, including procurement contracts and nonprocurement contracts. Both of these contracts involve the state budget. However, they are different in particular aspects. If procurement contract causes expense on the state budget, non-procurement contracts bring income to the state budget. Regarding to the authority within, government contract implemented by Commitment-Making Officials/PPK refers to procurement contracts on goods and service.

In respect to the government contract, the emerging maladministration, which inflicts national financial loss is more likely to be an alarming phenomenon. Regardless of how many officials or former officials arrested by KPK (Commission of Anti-Corruption), misusing government contracts is found as bad habits in the government of Indonesia. The establishment of an anti-corruption body indicates an abnormal condition in the implementation of Indonesia government, in particular to the state budget which involves the implementation of government contracts.

To prevent the misuse of government contract, Presidential decree No. 54/2010, lastly amended by Presidential decree No. 70/2012, on government goods/service procurement has asserted the principles of procurement: efficient, effective, transparent, open, competitive, fair, and accountable. In addition, it also set the ethics of procurement by asserting that every party involved in the implementation of goods/service procurement should avoid and prevent any misuse of authority and/or any collusion for either personal, group, or other purposes which directly/indirectly harm the state.

Regarding to accountability, article 122 Presidential decree No. 54, 2010, lastly amended by Presidential decree No. 70/2012 on government goods/service procurement, has mentioned that PPK breaking the agreement contained in a contract could be charged with compensation under several conditions as follow.

a. The amount of compensation paid by PPK due to the tardiness of payment is as big as the interest of the overdue bills, measured based on current interest rate as the provision of Bank Indonesia; or

b. Compensation is given based on the provision set in the contract.

The provision on accountability refers to any tort done by PPK as the authorized officials who sign and implement the government contracts. The state liability involved the government accountability on compensation which should be done through court. Based on theory of representation and liability, the basis of the state liability/ 
accountability on what PPK has done is the state performance and individual performance as human. Government is a legal body which representative refers to the people who perform for the government. The government must be represented by those people.

Basically, each authority used by the officials is always embedded with responsibility, as in accordance to the principle of "deen bevoegdheid zonder verantwoordenlijkheid" (no authority without responsibility). Sri Sumantri noted that each of authorization toward the government officials had responsibility attached within. ${ }^{23}$ Furthermore, Bothlingk stated that authority and responsibility attached within particular function is conducted by human being (natuurlijke persoon), acting as the representative of the function and known as the stakeholders or the officials. ${ }^{24}$

As the authority is attached within a function but the implementation is conducted by human as the representative or the functionary, deciding who should take the legal responsibility when irrelevancy happen needs to be casuistically considered since such responsibility may involve either job accountability or personal accountability. Although the authority is attached to the function along with the possible consequences, the responsibility in implementing the authority can be charged to the official in personal (in persoon). Conseil d'Etat based on the consideration of tribunal de conflict has determined two gauges of fault dealing with the amends that should be responsible for as follows personal fault (faute personelle); and employment fault (faute de serice).

Stated that faute personelle may happen if it derives from personal fault of an individual which becomes the part of the government. The fault shows one's limitation, desire, and careless or negligence. The officials who did the fault can be sued on ordinary court by the injured party. They are charged as personal and should be responsible for their fault. On the other hand, employment fault (faute de serice) may happen due to the misuse of authority and solely relates to the service issue. It should be filed to administrative court when such fault happens.

Following Bothlingk, the officials were fully responsible with their immoral practices due to the sake of the third party purposes. An individual is personally responsible toward the third party when they are found doing immoral practices, having bad faith, or being careless, which conducting maladministration. ${ }^{25}$

Etymologically, the term maladministration derives from Latin 'mal' referring to bad, and 'administrare' referring to serve. Thus, maladministration is identified as bad service. ${ }^{26}$ Sadjijono defined the term maladministration as behavior as well as procedures not solely restricted by administration matters. Maladministration does not merely refer to the breach of procedures of implementing a particular function by legal officials, but also refers to lawlessness (Onrechmatige overheidsdaad).

Commonly, maladministration is defined as action against the law and ethics (lawlessness) in a process of administration for public service. It includes the misuse of authority/function, negligence in decision making, ignorance of legal liability,

\footnotetext{
23 Sri Soemantri. (2006). Prosedur dan Sistem Perubahan Konstitusi. Bandung: Alumni. p. 7.

24 F.R.Bothlingk. (1954). Het Leerstuk der Vertegenwoordiging en Zijn Toepassing op Ambtsdragers in Nederland en in Indonesia. Nederland: Juridische Boekhandel en Uitgeverrij A. Jongbloed \& Zoon's Gravenhage. p. 32.

25 Ibid., p. 142.

26 Philipus M. Hadjon, et.al. (2011). Hukum Administrasi dan Tindak Pidana Korupsi. Yogyakarta: Gadjah Mada University Press. p. 19-20.
} 
conducting protracted delay, discriminative behavior, extortion, and any other maladministration considered similar to those kinds of fault. 27

In juridical context, the definition of maladministration can be found in article 1 section (3) the Law No. 37/2008 on Ombudsman of the Republic of Indonesia defining the term maladministration as lawlessness, going beyond the authority, using the authority for particular purposes outside the authority's interest, including negligence or ignorance of legal liability, which inflict material/immaterial loss toward society and individuals, in public service delivery done by the government and the state organizer.

Lawlessness is a term derived from Wederrechtelijk. In a doctrine about Wederrechtelijk, there are two major streams: Wederrechterlijk formil and Wederrechtrelijk materil. Lawlessness on formal law referred to (written) positive law, and lawlessness on substantive law refers to any actions against the norms of unwritten law. ${ }^{28}$ Additionally, the misuse of authority may point to the authorized official who acts against the law, or misusing the authority for another purpose beyond the authority. ${ }^{29}$ Hence, if the official performs against the authority he/she has or uses the authority for other purposes beyond the authority, he/she can be considered performing actions against the law (lawlessness). As the consequence, he/she is responsible with what he/she did.

\section{Conclusion}

Government contract is a contract in which the government involves as a contracting party. In this case, Commitment-Making Officials is the authorized officials who establish the draft of the contract, sign the contract, implement the contract, and control the implementation of the contract of goods and service procurement. As the organizers of governmental matters, Commitment-Making Officials who put another party into disadvantageous condition must be accountable/responsible as the officials when torts happen on the provisions of government contract they have made and signed. They are also responsible as the personal when they did maladministration such as misusing the authority delegated to them.

\section{References}

Agus Yudha Hernoko. (2016). "Prinsip-prinsip Tanggung Gugat Keperdataan”. Paper. Surabaya: Fakultas Hukum Universitas Airlangga.

Ahmad Sukardja. (2012). Hukum Tata Negara \& Hukum Administrasi Negara Dalam Perspektif Fikih Siyasah. Jakarta: Sinar Grafika.

Aleardo Zanghellini. (2016). “The Foundations of the Rule of Law”. Yale Journal of Law $\mathcal{E}$ the Humanities. Volume 28, Issue 2, Article 2: 213-240.

Dennis F. Thompson. (2000). Political Ethics and Public Office. Translated by Benyamin Molan-Ed. Jakarta: Yayasan Obor Indonesia. pp. 48-59.

Kolpinskaya, E., Katz, G., Banducci, S., Stevens, D., \& Coan, T. (2019). Mandates matter: how decisive victories enhance expectations about government performance. Journal of Elections, Public Opinion and Parties, 1-20.

27 Hendra Nurtjahjo, Yustus Maturbongs and Diani Indah Rachmitasari. (2013). Memahami Maladministrasi. Jakarta: Ombudsman Republik Indonesia. p. 4.

28 See Aleardo Zanghellini. (2016). "The Foundations of the Rule of Law". Yale Journal of Law $\mathcal{E}$ the Humanities. Volume 28, Issue 2, Article 2: 213-240.

29 Tatiek Sri Djatmiati. (2016). “Tanggung Jawab Pribadi dan Tanggung Jawab Jabatan”. Paper. Surabaya: Fakultas Hukum Universitas Airlangga. p. 3. 
E.R. Yescombe and Edward Farquharson. (2018). Public Private Partnerships for Infrastructure: Principles of Policy and Finance. 2nd Edition. Oxford: Elsevier Ltd.

F.R.Bothlingk. (1954). Het Leerstuk der Vertegenwoordiging en Zijn Toepassing op Ambtsdragers in Nederland en in Indonesia. Nederland: Juridische Boekhandel en Uitgeverrij A. Jongbloed \& Zoon's Gravenhage.

Hendra Nurtjahjo, Yustus Maturbongs and Diani Indah Rachmitasari. (2013). Memahami Maladministrasi. Jakarta: Ombudsman Republik Indonesia.

H.D. van Wijk/Willem Konijnenbelt. (1988). Hoofdstukken van Administratief Recht. Culemborg: Uitgeverij LEMMA BV.

H.R. Ridwan. (2006). Hukum Administrasi Negara. Jakarta: Rajawali Pers.

I Dewa Gede Atmadja and I Nyoman Putu Budiartha. (2018). Teori-Teori Hukum. Malang: Setara Press.

Jacob Hans Nieuwenhuis. (1985). Hoofdstukken Verbintenissenrecht. translated by Djasadin Saragih. Surabaya: Universitas Airlangga.

Michael Harper. (2017). "Using the Anglo-American Respondeat Superior Principle to Assign Responsibility for Worker Statutory Benefits and Protections". Public Law Research Paper. Boston University. School of Law.

Natalya Mosunova. (2014). "The Content of Accountability in Corporate Governance". Russian Law Journal, Volume II, Issue 3: 116-129.

Neculai Lungeanu. (2017). “Conceptual Aspects of the Legislative Delegation within the Romanian Law and the Law of other States". Acta Universitatis Danubius. Vol.9, No. 2: 60-72.

Nicken Sarwo Rini. (2018). "Penyalahgunaan Kewenangan Administrasi dalam Undang-Undang Tindak Pidana Korupsi”. Jurnal Penelitian Hukum De Jure. Vol.18 No.2. Juni: 257-274.

Pekka Valkama, Stephen J. Bailey and Ari-Veikko Anttiroiko (ed). (2013). Organizational Innovation in Public Services, Forms and Governance. London: Palgrave Macmillan.

Peter Mahmud Marzuki. (2013). Pengantar Ilmu Hukum. Jakarta: Kencana Prenada Media.

Philipus M. Hadjon, et.al. (2010). Hukum Administrasi dan Good Governance. Jakarta: Universitas Trisakti.

Philipus M. Hadjon, et.al. (2011). Hukum Administrasi dan Tindak Pidana Korupsi. Yogyakarta: Gadjah Mada University Press.

Prajudi Atmosudirdjo. (1981). Hukum Administrasi Negara. Jakarta: Ghalia Indonesia.

Sri Soemantri. (2006). Prosedur dan Sistem Perubahan Konstitusi. Bandung: Alumni.

Tatiek Sri Djatmiati. (2016). “Tanggung Jawab Pribadi dan Tanggung Jawab Jabatan”. Paper. Surabaya: Fakultas Hukum Universitas Airlangga.

Tim AFDES. (2013). Kerjasama Pemerintah Swasta. Jakarta: Aid for Development Effectiveness Secretariat.

Yohanes Sogar Simamora. (2013). Hukum Kontrak, Kontrak Pengadaan Barang dan Jasa Pemerintah di Indonesia. Surabaya: Laksbang Justitia.

\section{Conflict of Interest Statement:}

The author(s) declares that the research was conducted in the absence of any commercial or financial relationships that could be construed as a potential conflict of interest.

Copyright (C) 2019 HALREV. All rights reserved. 